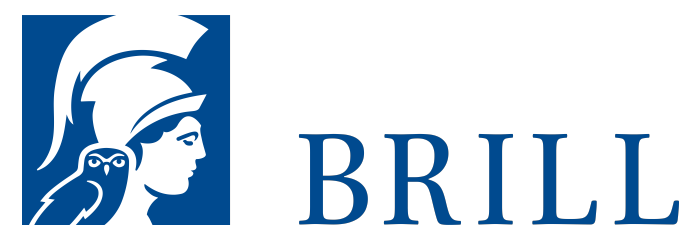

\title{
Soldat ohne Befehl
}

Ernst von Salomon und der Soldatische Nationalismus

Author: Gregor Fröhlich

Diese Biographie Ernst von Salomons (1902-1972) zeichnet den Lebensweg eines der umstrittensten Schriftsteller des 20. Jahrhunderts nach. Salomon verkörpert wie nur wenige die wilhelminische Jugend, welche nach 1918 eine Welt im Umbruch erfuhr. Die soziale Desintegration des preußischen Kadettenschülers steigerte sich nach Kriegserfahrung in den Freikorps zu einer erbitterten Feindschaft gegen die Weimarer Republik. Auch nach Haftstrafen aufgrund der Ermordung Walther Rathenauss blieb die antiliberale Geisteshaltung als weltanschaulicher Kompass für Ernst von Salomon bestehen. Das Psychogramm Salomons gibt Einblicke in die abgeschottete Welt der militanten Verschwörer der 192oer Jahre und die sozialen Mechanismen, welche nötig waren paramilitärische Kriegerbünde aufrechtzuerhalten. Terror und Gewalt waren hierfür ebenso Kennzeichen wie das Sehnen nach einem Leben in Funktion. So bleiben Salomons Romane Zeugen eines literarischen Projekts der antimodernen Moderne.

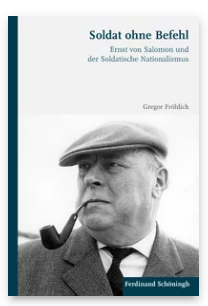

Pages: 426

Seiten

Language:

German

Subjects:

Modern History,

History

Publisher: Brill |

Schöningh

E-Book (PDF)

Released online:

24 Nov 2017

ISBN: 978-3-

657-78738-8

List price

Hardback

Publication date: 10 Nov 2017

ISBN: 978-3506-78738-5

List price 
For more information see brill.com

Order information: Order online at brill.com +44330 333 0049 | customerservices@brill.com Submission information: brill.com/authors

Titles published by Brill | Fink, Brill | mentis or Brill | Schöningh: +49(o)715413279216| brill@brocom.de 